\title{
TWO FIGURES LYING ON A BED WITH ATTENDANTS
}

\section{Mary Szybist}

Oil and pastel on canvas, 1968

\section{PANEL ONE}

The first sits. He crosses his legs and stares.

He has been attending them a long time.

He has learned, at last, to position himself.

His arms must stay close to his body.

See, he demonstrates, I do this even in a chair, dropping

the short flat bone in my elbow.

You have no proper...

while he goes on like this

leaning forward, drawing himself back

a bird is springing from the hole in the floor, is darting toward the couple-It is a stork.

It craves nakedness. It is ready to complete the man's movement.

\section{PANEL THREE}

There are more in attendance.

A man dressed in a gray suit, a black shoe, his left arm bent as if to conduct a closing of the bed, two spines heaped across it$h e$ is not a man to spend nights showing nothing but the frivolous small of his back.

He has managed a tactful arrangement of his spilling, it sits at his heels like a dog, its face that of a dog, it is complicit with the man, they leer in the direction of the bed- 
If he had a mouth to voice his open face, he would say sluts and children-

you are not enough to know what is coming.

\section{PANEL TWO}

The one good eye of the room

wide open on the pillow, on the most legible head.

Why else would two people shut

their green blinds and half

fall into each other?

No, it is true this time.

They are loved. 